\title{
Nocardioides panacihumi sp. nov., isolated from soil of a ginseng field
}

\author{
Correspondence \\ Min-Ho Yoon \\ mhyoon@cnu.ac.kr
}

\author{
Dong-Shan An, ${ }^{1}$ Wan-Taek Im, ${ }^{1}$ Sung-Taik Lee ${ }^{1}$ and Min-Ho Yoon ${ }^{2}$
}

\begin{abstract}
${ }^{1}$ Department of Biological Sciences, Korea Advanced Institute of Science and Technology, 373-1, Guseong-dong, Yuseong-gu, Daejeon 305-701, Republic of Korea

${ }^{2}$ Department of BioEnvironmental Chemistry, College of Agriculture and Life Sciences, Chungnam National University, Gung-dong 22, Yuseong-gu, Daejeon 305-764, Republic of Korea
\end{abstract}

\begin{abstract}
A novel bacterial strain designated Gsoil $616^{\top}$ was isolated from a soil sample of a ginseng field in Pocheon province (South Korea) and was characterized taxonomically by using a polyphasic approach. The isolate was Gram-positive, strictly aerobic, non-motile, non-spore-forming and rod- or coccoid-shaped. Phylogenetic analysis based on 16S rRNA gene sequences indicated that the isolate belongs to the genus Nocardioides in the family Nocardioidaceae but was clearly separated from established species of this genus. The 16S rRNA gene sequence similarities between strain Gsoil $616^{\top}$ and the type strains of Nocardioides species with validly published names ranged from 91.8 to $96.1 \%$. The $\mathrm{G}+\mathrm{C}$ content of the genomic DNA was $73 \mathrm{~mol} \%$. Phenotypic and chemotaxonomic data [major menaquinone $\mathrm{MK}-8\left(\mathrm{H}_{4}\right)$ and major fatty acid iso- $C_{16: 0}$ ] supported the affiliation of strain Gsoil $616^{\top}$ to the genus Nocardioides. However, the results of physiological and biochemical tests allowed phenotypic differentiation of the isolate from other Nocardioides species. Therefore, strain Gsoil $616^{\top}$ represented a novel species within the genus Nocardioides, for which the name Nocardioides panacihumi sp. nov. is proposed. The type strain is Gsoil $616^{\top}\left(=\right.$ KCTC $19187^{\top}=$ DSM $\left.18660^{\top}\right)$.
\end{abstract}

The genus Nocardioides was proposed by Prauser (1976) and, at the time of writing, it comprises 20 recognized species, including the recently described species Nocardioides furvisabuli (Lee, 2007) and Nocardioides insulae (Yoon et al., 2007). Strain Gsoil $616^{\mathrm{T}}$ was isolated from soil of a ginseng field in Pocheon province, South Korea, during the study of bacterial populations and was tentatively identified as Nocardioides sp. (Im et al., 2005). The isolation procedure and medium were described by Cui et al. (2007). Strain Gsoil $616^{\mathrm{T}}$ was routinely cultured on R2A agar (Difco) or half-strength R2A agar at $30{ }^{\circ} \mathrm{C}$ and maintained in glycerol suspension $\left(20 \%\right.$, w/v) at $-70{ }^{\circ} \mathrm{C}$.

The Gram reaction was performed by the non-staining method as described by Buck (1982). Cell morphology was observed at $\times 1000$ magnification with a light microscope (Nikon) using cells grown for 3 days at $30{ }^{\circ} \mathrm{C}$ on R2A agar. Motility was tested using the hanging drop technique. Catalase activity was determined by bubble production in $3 \%(\mathrm{v} / \mathrm{v}) \mathrm{H}_{2} \mathrm{O}_{2}$ and oxidase activity was determined using $1 \%(\mathrm{w} / \mathrm{v})$ tetramethyl $p$-phenylenediamine. Carbon-source utilization and enzyme activities were tested by using the

The GenBank/EMBL/DDBJ accession number for the 16S rRNA gene sequence of strain Gsoil $616^{\top}$ is AB271053.

A comparison of the fatty acid profile of strain Gsoil $616^{\top}$ and related type strains is available as supplementary material with the online version of this paper.
API 20 NE, API ID 32 GN, API $50 \mathrm{CH}$ and API ZYM test kits (bioMérieux). Anaerobic growth was tested in serum bottles with sodium thioglycolate $\left(1 \mathrm{~g} \mathrm{l}^{-1}\right)$ added to R2A broth and replacing the upper air layer with nitrogen gas. Tests for the degradation of DNA [with DNase agar (Scharlau); performed by flooding plates with $1 \mathrm{M} \mathrm{HCl}$, casein, chitin, starch (Atlas, 1993), xylan and cellulose (Ten et al., 2004) were evaluated after 2 weeks. Growth at different temperatures $\left(4,15,20,25,30,37\right.$ and $\left.42{ }^{\circ} \mathrm{C}\right)$ and $\mathrm{pH}$ values ( $\mathrm{pH}$ 5.0-10.0 at intervals of $0.5 \mathrm{pH}$ units) was assessed after 5 days incubation. Salt tolerance was tested on R2A agar supplemented with $1-10 \%$ (w/v) $\mathrm{NaCl}$ after 5 days incubation. Growth on nutrient agar, trypticase soy agar (TSA) and MacConkey agar was also evaluated, at $30{ }^{\circ} \mathrm{C}$.

Cells of strain Gsoil $616^{\mathrm{T}}$ were strictly aerobic, Grampositive, non-motile, non-spore-forming and rod- or coccoid-shaped. Colonies grown on R2A agar plates for 3 days were smooth, circular, white and $1-3 \mathrm{~mm}$ in diameter. The isolate grew well on nutrient agar and TSA, whereas it could not grow on MacConkey agar. Other physiological characteristics of strain Gsoil $616^{\mathrm{T}}$ are summarized in the species description. Phenotypic characteristics that differentiate the isolate from its closest phylogenetic relatives are listed in Table 1.

The study of DNA G $+\mathrm{C}$ content and chemotaxonomic characters was carried out as described previously (Cui 
Table 1. Comparison of the phenotypic characteristics of strain Gsoil $616^{\top}$ and related species of genus Nocardioides

Strains/species: 1, Gsoil $616^{\mathrm{T}} ; 2$, Nocardioides luteus; 3, Nocardioides aquiterrae GW-9 ${ }^{\mathrm{T}} ; 4$, Nocardioides pyridinolyticus $\mathrm{OS}^{\mathrm{T}}$; 5, Nocardioides albus (data in parentheses are for the type strain). Data for reference taxa were taken from Yoon et al. (2006). All taxa were positive for utilization of Dfructose, D-glucose, sucrose and D-xylose, hydrolysis of gelatin and leucine arylamidase and trypsin activities and negative for hydrolysis of urea and lipase $\left(\mathrm{C}_{14}\right), \alpha$-galactosidase and $\alpha$-chymotrypsin activities. + , Positive; - , negative; $\mathrm{v}$, variable reaction; $\mathrm{W}$, weakly positive reaction; ND, no data available.

\begin{tabular}{|c|c|c|c|c|c|}
\hline Characteristic & 1 & 2 & 3 & 4 & 5 \\
\hline Cell morphology & Short rods, cocci & Hyphae & Rods, cocci & Rods, cocci & Hyphae \\
\hline Cell size $(\mu \mathrm{m})$ & $0.3-0.5 \times 0.7-1.2$ & $0.5-1.0^{*}$ & $0.8-1.0 \times 1.7-2.0$ & $0.5-0.6 \times 1.2-1.6$ & $0.5-1.0^{\star}$ \\
\hline Motility & - & - & + & + & - \\
\hline Colony colour & White & $\begin{array}{c}\text { Yellow to orange-yel- } \\
\text { low or cream }\end{array}$ & Cream & Cream & $\begin{array}{c}\text { Whitish to faintly } \\
\text { brownish }\end{array}$ \\
\hline Nitrate reduction & + & - & + & + & $(-)$ \\
\hline \multicolumn{6}{|l|}{ Hydrolysis of: } \\
\hline Aesculin & + & + & + & + & (w) \\
\hline Starch & - & + & - & + & $(+)$ \\
\hline \multicolumn{6}{|l|}{$\begin{array}{l}\text { Utilization as sole carbon and } \\
\text { energy sources of: }\end{array}$} \\
\hline D-Cellobiose & - & + & + & + & $(+)$ \\
\hline D-Galactose & - & - & + & + & $(+)$ \\
\hline D-Mannitol & - & + & + & + & + \\
\hline D-Mannose & - & + & + & + & $(+)$ \\
\hline D-Raffinose & + & - & - & - & $\mathrm{V}(-)$ \\
\hline Trehalose & - & ND & + & + & ND \\
\hline \multicolumn{6}{|l|}{ API ZYM tests } \\
\hline Alkaline phosphatase & + & $\mathrm{V}$ & - & + & $(+)$ \\
\hline Esterase $(\mathrm{C} 4)$ & + & + & - & - & $(+)$ \\
\hline Valine arylamidase & $\mathrm{w}$ & - & - & $\mathrm{W}$ & $(-)$ \\
\hline Cystine arylamidase & $\mathrm{W}$ & - & $\mathrm{W}$ & - & $(-)$ \\
\hline Acid phosphatase & + & - & + & + & $(-)$ \\
\hline$\beta$-Galactosidase & - & $\mathrm{v}$ & - & - & (v) \\
\hline$\alpha$-Glucosidase & + & $\mathrm{V}$ & + & + & $(+)$ \\
\hline$\beta$-Glucosidase & + & - & w & - & $(\mathrm{w})$ \\
\hline$\alpha$-Mannosidase & + & - & W & - & (w) \\
\hline Isolation source & Soil & Soil & Groundwater & Oil-shale column & Soil \\
\hline DNA G $+\mathrm{C}$ content $(\mathrm{mol} \%)$ & 73 & 68 & 73 & 73 & 67 \\
\hline
\end{tabular}

${ }^{\star}$ Cell width is shown.

et al., 2007). The $\mathrm{G}+\mathrm{C}$ content of genomic DNA of strain Gsoil $616^{\mathrm{T}}$ was $73 \mathrm{~mol} \%$. Cellular fatty acids were determined in a culture grown on R2A agar for 6 days. The fatty acid profile of strain Gsoil $616^{\mathrm{T}}$ (compared with those of related type strains in Supplementary Table S1 in IJSEM Online) was composed of branched-chain fatty acids iso- $\mathrm{C}_{16: 0} \quad(45.5 \%)$, iso- $\mathrm{C}_{15: 0} \quad(3.8 \%)$, iso- $\mathrm{C}_{14: 0}$ $(2.9 \%)$, iso- $\mathrm{C}_{15: 0} 3-\mathrm{OH}(1.5 \%)$, iso- $\mathrm{C}_{17: 0}(0.9 \%)$, anteiso- $\mathrm{C}_{15: 0}(0.8 \%)$, anteiso- $\mathrm{C}_{17: 0}(0.8 \%)$ and iso- $\mathrm{C}_{18: 0}$ $(0.5 \%)$, unsaturated fatty acids $\mathrm{C}_{17: 1} \omega 6 c \quad(7.5 \%)$, $\mathrm{C}_{17: 1} \omega 8 c \quad(3.6 \%), \quad \mathrm{C}_{18: 1} \omega 9 c \quad(2.8 \%)$ and $\mathrm{C}_{18: 3} \omega 6 c$ $(6,9,12)(2.1 \%)$, saturated fatty acids $\mathrm{C}_{16: 0}(6.4 \%), \mathrm{C}_{17: 0}$ (5.9\%), $\mathrm{C}_{18: 0}(4.4 \%), \mathrm{C}_{15: 0}(1.6 \%)$ and $\mathrm{C}_{14: 0}(0.9 \%), 10-$ methyl fatty acids $\mathrm{C}_{17: 0}(2.8 \%), \mathrm{C}_{16: 0}(1.0 \%)$ and $\mathrm{C}_{18: 0}$ $(0.9 \%)$ and summed feature 7 (any combination of $\mathrm{C}_{18: 1} \omega 7 c, \mathrm{C}_{18: 1} \omega 9 t$ and $\left.\mathrm{C}_{18: 1} \omega 12 t\right)(1.4 \%)$, summed feature 3 (iso- $\mathrm{C}_{15: 0} 2-\mathrm{OH}$ and/or $\left.\mathrm{C}_{16: 1} \omega 7 c\right)(1.1 \%)$ and summed feature $6\left(\mathrm{C}_{18: 2} \omega 6,9 c\right.$ and/or anteiso- $\left.\mathrm{C}_{18: 0}\right)$ $(0.4 \%)$. This fatty acid profile, including the major fatty acid iso- $\mathrm{C}_{16: 0}$ and three 10-methyl fatty acids, is similar to those of Nocardioides species, although there are differences in the proportions of some fatty acids, perhaps because of differences in the extraction and cultivation conditions (Yoon et al., 1997, 2004; Yi \& Chun, 2004a, b). LLDiaminopimelic acid and the predominant menaquinone MK-8 $\left(\mathrm{H}_{4}\right)$ were also typical of members of the genus Nocardioides (Yoon et al., 1997, 2004, Yi \& Chun, 2004a, b).

Extraction of genomic DNA, PCR-mediated amplification of the 16S rRNA gene and sequencing of the purified PCR product were carried out according to Kim et al. (2005). The full sequence of the 16S rRNA gene was compiled using SeqMan software (DNASTAR). The 16S rRNA gene sequences of related taxa were obtained from GenBank. 
Multiple alignments were performed by using the CLUSTAL_X program (Thompson et al., 1997) and gaps were edited in the BioEdit program (Hall, 1999). Evolutionary distances were calculated using the Kimura two-parameter model (Kimura, 1983) and phylogenetic trees were constructed by using the neighbour-joining method (Saitou \& Nei, 1987) using the MEGA3 program (Kumar et al., 2004) with bootstrap values based on 1000 replications (Felsenstein, 1985).

The nearly complete $16 \mathrm{~S}$ rRNA gene sequence (1457 bp) of strain Gsoil $616^{\mathrm{T}}$ was determined and subjected to phylogenetic analysis, which indicated that strain Gsoil $616^{\mathrm{T}}$ belongs to the genus Nocardioides (Fig. 1). Strain Gsoil $616^{\mathrm{T}}$ showed highest 16S rRNA gene sequence similarity to Nocardioides luteus KCTC $9575^{\mathrm{T}}$ and Nocardioides aquiterrae GW- $9^{\mathrm{T}}$ (96.1\%), followed by Nocardioides pyridinolyticus KCTC $0074 \mathrm{BP}^{\mathrm{T}}(95.5 \%)$ and other species of Nocardioides $(<95 \%)$. These values $(<97 \%)$ were low enough to place strain Gsoil $616^{\mathrm{T}}$ within a novel species of the genus Nocardioides according to Stackebrandt \& Goebel (1994).

On the basis of the data described above, strain Gsoil $616^{\mathrm{T}}$ should be assigned to the genus Nocardioides as the type strain of a novel species, for which the name Nocardioides panacihumi sp. nov. is proposed.

\section{Description of Nocardioides panacihumi sp. nov.}

Nocardioides panacihumi (pa.na.ci.hu'mi. N.L. n. Panax scientific name of ginseng; N.L. gen. n. panacis of ginseng; L. n. humus soil; N.L. gen. n. panacihumi of soil of a ginseng field).

Cells are Gram-positive, strictly aerobic and non-motile, $0.3-0.5 \mu \mathrm{m}$ in diameter and $0.7-1.2 \mu \mathrm{m}$ long after 3 days on R2A agar. Cells show rod-to-coccus morphogenesis from the early exponential phase to the stationary phase. Colonies grown on R2A agar (Difco) for 3 days are smooth, circular, convex, opaque and white. Neither substrate mycelium nor aerial mycelium is formed. Good growth occurs at $30{ }^{\circ} \mathrm{C}$ and at $\mathrm{pH}$ 7.0. Growth is observed at $15-30{ }^{\circ} \mathrm{C}$, pH $5.0-8.0$ and in $0-1 \%(\mathrm{w} / \mathrm{v}) \mathrm{NaCl}$. Nitrate is reduced weakly under aerobic conditions. Anaerobic growth does not occur. DNA and casein are degraded but xylan, cellulose, starch and chitin are not. Substrate utilization, enzyme production and other physiological characteristics are indicated in Table 1 . In addition to the properties listed in Table 1, acetate, L-alanine, gluconate, glycogen, 3-hydroxybenzoate, 4-hydroxybenzoate, 3hydroxybutyrate, maltose, phenylacetate, L-proline, propionate, L-rhamnose, salicin and valerate are utilized as sole carbon sources. $N$-Acetyl- $\beta$-glucosamine, adipate, L-arabinose, caprate, citrate, L-fucose, L-histidine, inositol, itaconate, 2-ketogluconate, 5-ketogluconate, L-lactate, malate, malonate, mannitol, D-melibiose, D-ribose, L-serine, Dsorbitol and suberate are not utilized as sole carbon sources. In API $50 \mathrm{CH}$ tests, acid is produced from amygdalin, L-arabinose, aesculin ferric citrate, D-glucose, D-fructose, D-lyxose, D-raffinose, L-rhamnose, sucrose and D-turanose, but acid is not produced from $\mathrm{N}$-acetylglucosamine, L-arabinose, DL-arabitol, arbutin, adonitol, starch, D-cellobiose, dulcitol, erythritol, DL-fucose, D-galactose, gentiobiose, glycerol, glycogen, methyl $\alpha$-glucopyranoside, gluconate, inositol, inulin, 2- or 5-ketogluconate, D-lactose, D-lyxose, maltose, D-mannitol, D-mannose, methyl $\alpha$-Dmannoside, melezitose, melibiose, ribose, salicin, D-sorbitol, L-sorbose, D-tagatose, trehalose, xylitol, L-xylose or methyl $\beta$-D-xyloside. According to the API ZYM gallery, the type strain is positive for $N$-acetyl- $\beta$-glucosaminidase, esterase lipase (C8) and $\alpha$-fucosidase and negative for $\beta$ glucuronidase and naphthol-AS-BI-phosphohydrolase. According to the API 20NE gallery, the type strain is positive for $\beta$-glucosidase but negative for arginine dihydrolase, $\beta$-galactosidase, tryptophan degradation and glucose fermentation. The diagnostic diamino acid in the cell-wall peptidoglycan is LL-2,6-diaminopimelic acid. The

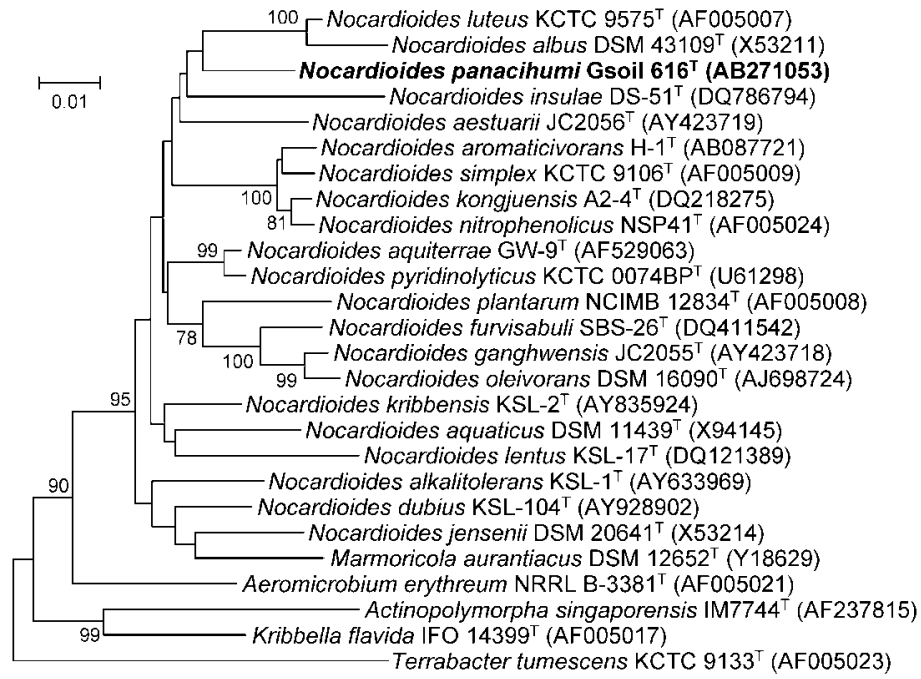

Fig. 1. Phylogenetic tree constructed from a comparative analysis of $16 \mathrm{~S}$ rRNA gene sequences showing the relationships of strain Gsoil $616^{\top}$ with related species. The tree was made using the neighbour-joining method (Saitou \& Nei, 1987) with a two-parameter distance matrix (Kimura, 1983) and pairwise deletion. Bootstrap values (expressed as percentages of 1000 replications) greater than $70 \%$ are shown at branch points. Bar, 0.01 substitutions per nucleotide position. 
predominant menaquinone is $\mathrm{MK}-8\left(\mathrm{H}_{4}\right)$. The major fatty acid ( $>45 \%$ of total fatty acids) is iso- $\mathrm{C}_{16: 0}$. The $\mathrm{G}+\mathrm{C}$ content of genomic DNA of the type strain is $73 \mathrm{~mol} \%$. Other phenotypic characteristics are given in Table 1.

The type strain, Gsoil $616^{\mathrm{T}}$ (=KCTC $19187^{\mathrm{T}}=\mathrm{DSM}$ $18660^{\mathrm{T}}$ ), was isolated from soil of a ginseng field of Pocheon province, South Korea.

\section{Acknowledgements}

This work was supported by a grant from the Korea Science and Engineering Foundation, Ministry of Science and Technology, Republic of Korea. We thank Jean Euzéby for his help with the etymology of the species epithet.

\section{References}

Atlas, R. M. (1993). Handbook of Microbiological Media. Edited by L. C. Parks. Boca Raton, FL: CRC Press.

Buck, J. D. (1982). Nonstaining ( $\mathrm{KOH})$ method for determination of gram reactions of marine bacteria. Appl Environ Microbiol 44, 992-993.

Cui, Y.-S., Im, W.-T., Yin, C.-R., Yang, D.-C. \& Lee, S.-T. (2007). Microlunatus ginsengisoli sp. nov., isolated from soil of a ginseng field. Int J Syst Evol Microbiol 57, 687-691.

Felsenstein, J. (1985). Confidence limits on phylogenies: an approach using the bootstrap. Evolution 39, 783-791.

Hall, T. A. (1999). BioEdit: a user-friendly biological sequence alignment editor and analysis program for Windows 95/98/NT. Nucl Acids Symp Ser 41, 95-98.

Im, W.-T., Jung, H.-M., Cui, Y.-S., Liu, Q.-M., Zhang, S.-L. \& Lee, S.-T. (2005). Cultivation of the three hundreds of bacterial species from soil of a ginseng field and mining the novel lineage bacteria. In Proceedings of the International Meeting of the Federation of Korean Microbiological Societies, abstract A035, p. 169. Seoul: Federation of Korean Microbiological Societies.

Kim, M. K., Im, W.-T., Ohta, H., Lee, M. \& Lee, S.-T. (2005). Sphingopyxis granuli sp. nov., a $\beta$-glucosidase-producing bacterium in the family Sphingomonadaceae in $\alpha-4$ subclass of the Proteobacteria. J Microbiol 43, 152-157.
Kimura, M. (1983). The Neutral Theory of Molecular Evolution. Cambridge: Cambridge University Press.

Kumar, S., Tamura, K. \& Nei, M. (2004). MEGA3: integrated software for molecular evolutionary genetics analysis and sequence alignment. Brief Bioinform 5, 150-163.

Lee, S. D. (2007). Nocardioides furvisabuli sp. nov., isolated from black sand. Int J Syst Evol Microbiol 57, 35-39.

Prauser, H. (1976). Nocardioides, a new genus of the order Actinomycetales. Int J Syst Bacteriol 26, 58-65.

Saitou, N. \& Nei, M. (1987). The neighbor-joining method: a new method for reconstructing phylogenetic trees. Mol Biol Evol 4, 406-425.

Stackebrandt, E. \& Goebel, B. M. (1994). Taxonomic note: a place for DNA-DNA reassociation and 16S rRNA sequence analysis in the present species definition in bacteriology. Int J Syst Bacteriol 44, 846-849.

Ten, L. N., Im, W.-T., Kim, M.-K., Kang, M.-S. \& Lee, S.-T. (2004). Development of a plate technique for screening of polysaccharidedegrading microorganisms by using a mixture of insoluble chromogenic substrates. J Microbiol Methods 56, 375-382.

Thompson, J. D., Gibson, T. J., Plewniak, F., Jeanmougin, F. \& Higgins, D. G. (1997). The CLUSTAL_X windows interface: flexible strategies for multiple sequence alignment aided by quality analysis tools. Nucleic Acids Res 25, 4876-4882.

Yi, H. \& Chun, J. (2004a). Nocardioides ganghwensis sp. nov., isolated from tidal flat sediment. Int J Syst Evol Microbiol 54, 1295-1299.

Yi, H. \& Chun, J. (2004b). Nocardioides aestuarii sp. nov., isolated from tidal flat sediment. Int J Syst Evol Microbiol 54, 2151-2154.

Yoon, J.-H., Rhee, S.-K., Lee, J.-S., Park, Y.-H. \& Lee, S. T. (1997). Nocardioides pyridinolyticus sp. nov., a pyridine-degrading bacterium isolated from the oxic zone of an oil shale column. Int J Syst Bacteriol 47, 933-938.

Yoon, J.-H., Kim, I.-G., Kang, K. H., Oh, T.-K. \& Park, Y.-H. (2004). Nocardioides aquiterrae sp. nov., isolated from groundwater in Korea. Int J Syst Evol Microbiol 54, 71-75.

Yoon, J.-H., Lee, C.-H. \& Oh, T.-K. (2006). Nocardioides lentus sp. nov., isolated from an alkaline soil. Int J Syst Evol Microbiol 56, 271-275.

Yoon, J.-H., Kang, S.-J., Lee, C.-H. \& Oh, T.-K. (2007). Nocardioides insulae sp. nov., isolated from soil. Int J Syst Evol Microbiol 57, 136-140. 